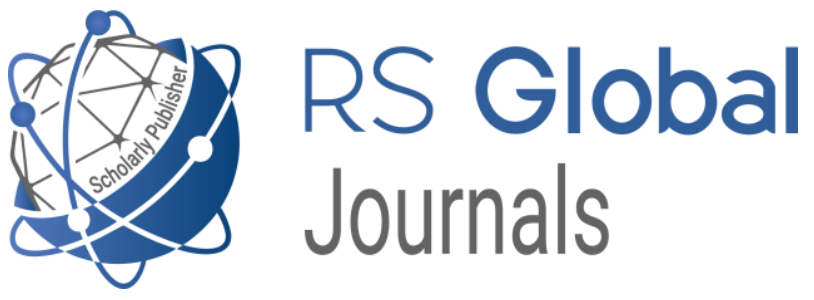

Scholarly Publisher

RS Global Sp. z O.O.

ISNI: 0000000484952390

Dolna 17, Warsaw, Poland 00-773

Tel: +48226022703

Email: editorial_office@rsglobal.pl

JOURNAL International Journal of Innovative Technologies in Social Science

p-ISSN $2544-9338$

e-ISSN

2544-9435

PUBLISHER

RS Global Sp. z O.O., Poland

ARTICLE TITLE

PSYCHOLOGICAL FACTORS OF EMOTIONAL INSTABILITY IN ADOLESCENTS

AUTHOR(S)

Gurak Halyna, Dolynska Lyubov

Gurak Halyna, Dolynska Lyubov. (2021) Psychological Factors of

ARTICLE INFO Emotional Instability in Adolescents. International Journal of Innovative Technologies in Social Science. 4(32). doi: 10.31435/rsglobal_ijitss/30122021/7705

DOI https://doi.org/10.31435/rsglobal_ijitss/30122021/7705

RECEIVED

08 October 2021

ACCEPTED

06 December 2021

PUBLISHED

09 December 2021

\title{
(ㄷ) (1)
}

LICENSE

This work is licensed under a Creative Commons Attribution 4.0 International License.

(C) The author(s) 2021. This publication is an open access article. 


\section{PSYCHOLOGICAL FACTORS OF EMOTIONAL INSTABILITY IN ADOLESCENTS}

Gurak Halyna, graduate student Department of Psychology at National Pedagogical Dragomanov University, Kyiv, Ukraine (2013-2016) https://orcid.org/0000-0002-7563-9349

Dolynska Lyubov, candidate of psychological sciences professor Secretary of the Specialized Academic Council for Pedagogical and Age Psychology, Head of the Department of Psychology, National Pedagogical Dragomanov University, Kyiv, Ukraine, halya304@ gmail.com, https://orcid.org/0000-0002-1817-1102

DOI: https://doi.org/10.31435/rsglobal_ijitss/30122021/7705

\section{ARTICLE INFO}

Received 08 October 2021

Accepted 06 December 2021

Published 09 December 2021

\section{KEYWORDS}

Adolescence, affective sphere, emotions, emotional instability, emotional stability, emotional dysregulation.

\begin{abstract}
The article presents an overview of the problem of the affective sphere of adolescents on both theoretical and empirical levels. Its relevance and, at the same time, the prospect for further research is justified. It was revealed that the emotional life of persons of pubertal period is differently disclosed in the scientific heritage of foreign scientists, but insufficiently covered in the domestic. Correlations between the emotional experiences of adolescents and their relationships with parents, peers; gender identity; eating disorders, etc., were established. Against the background of emphasizing the influence of various external psychological factors in the life of an adolescent, the topic of the intrapersonal, psychological potential of persons of this age remains open. Taking into account the topicality of the problem of emotional instability of teenagers, we aimed to find out in detail, from an empirical point of view, the internal psychological reasons of this phenomenon. For this purpose, the ascertaining experiment was carried out which involved 300 pupils of 6-7 and 8-9 forms of the general secondary educational institutions of the Ternopil region (Berezhanska Secondary School № 1 and Berezhanska Secondary School № 2). Respondents were offered specific, according to the formulated scientific problem, a package of psychodiagnostic techniques, directed to the research of features of the level of manifestation as well as categories of hypothetical factors of emotional stability of adolescents.

The next stage of the study involved processing the data by factor analysis using the capabilities of Microsoft Excel and SPSS 21 software. As a result, 10 psychological factors that cause emotional instability in adolescents were identified. Among them: imbalance of self-esteem and personal abilities, personal insecurity compensated by self-control, low resistance to stress, impulsiveness against insecurity, dissonance in the assessment of one's own self, motivational polarity, emotional uncertainty, public insecurity, uncertainty in own abilities, confident behavior.

The prospect of our study is the development and practical implementation of social psychological training as a means of correcting dysregulation of the affective sphere of personality and the development of their emotional stability.
\end{abstract}

Citation: Gurak Halyna, Dolynska Lyubov. (2021) Psychological Factors of Emotional Instability in Adolescents. International Journal of Innovative Technologies in Social Science. 4(32). doi: 10.31435/rsglobal_ijitss/30122021/7705

Copyright: (C) 2021 Gurak Halyna, Dolynska Lyubov. This is an open-access article distributed under the terms of the Creative Commons Attribution License (CC BY). The use, distribution or reproduction in other forums is permitted, provided the original author(s) or licensor are credited and that the original publication in this journal is cited, in accordance with accepted academic practice. No use, distribution or reproduction is permitted which does not comply with these terms.

Introduction. A component of the psychological architectonics of personality is the affective domain, of which emotions are a part. Their etymology, interpretation and possibilities of control are questions actively discussed both by psychology theorists and practitioners. The problem of the emotional 
experiences of the personality acquires particular urgency during puberty. Low stress-resistance, determined by sharp physiological metamorphoses, and also identity retouched under the influence of a reference group on a background of aspiration to self-expression - are obvious characteristics of this age.

It is safe to say that puberty is associated with the crisis that the individual experiences at this age stage. Indeed, the changes that occur are striking and cardinal, and most importantly, they manifest themselves both at the physiological level and in the psychological architectonics of the personality, affecting at the same time the affective sphere. The social situation of development provokes ambivalent feelings: the desire to communicate with peers, the search for new authorities and patterns of behavior as a manifestation of adulthood on the one hand, and infantilism and an internal unwillingness to sever emotional ties, emancipating oneself from adults on the other. This becomes a determinant of intrapersonal and interpersonal conflicts that can lead to an uncontrollable flow of emotions and experiences.

In spite of the fact that the leading type of activity during puberty is intimate personal communication with peers, we have revealed data that the emotional well-being of the teenager directly proportionally depends on the family microclimate, support or, on the contrary, criticism from significant people - parents. The style of upbringing and communication, the relationships between adults - all of these factors directly correlate with the child's general emotional background and his or her ability to adequately control the level of intensity of emotional reactions. The above are substantiated results of the scientific legacy of the team of authors: Mendo-Lázaro, León-Del-Barco, Polo-Del-Río, Yuste-Tosina, and LópezRamos (2019). A related study is Cheung, Chan, and Chung (2020), whose findings suggest a direct relationship between parental emotional dysregulation and adolescent internalizing problems.

Physiological metamorphosis, namely the emergence of secondary sex characteristics, prompts a new perception of not only one's body, but also an awareness of one's own gender identity. Sexual identification and emotional stability are closely related. This conclusion is prompted by the results of a study conducted among adolescent boys. Respondents who felt they lacked masculinity showed greater difficulties in emotion regulation and greater attraction to hypermasculinity (Roche et al., 2021). That is, in this case, the emotional instability was a manifestation of psychological tension due to an imbalance in gender identity.

Obviously, not a child, but not yet an adult, it is difficult for an adolescent to cope with internal contradictions and new demands imposed on the society. Therefore, conflicts and uncontrollable emotional outbursts become frequent. Given this fact, the problem of the emotional during puberty deserves special attention. In particular, the psychological factors determining the emotional instability of teenagers need detailed study.

The founder of the Research Institute for Problems of Development of Psychological and Emotional Stability in Children and Adults, Benard, n.d., distinguishes such external, social, factors in the development of the phenomenon in question:

1) Family (care and support of parents; expectations related to a sense of faith, a certain order and discipline in the family; encouragement of child participation in family life; respect for child autonomy; support for independence, etc.).

2) School or curricular (care and support from peers and friends; expectations of teachers; participation and involvement of adolescents in school life);

3) Social (care and support of society; availability of resources necessary for healthy development: health care, housing, education, recreation; cultural traditions; opportunity to participate in social life (in traditional societies the roles of all its members are distributed, which positively affects the development of emotional) resilience)) (Benard, n.d., 1991).

From the perspective of the problem under study, the "Big 5" theory, a joint effort of researchers from the U.S. and Great Britain, also deserves attention. It considers emotional resilience to be one of the basic constructs of personality, noting that locus of control, neuroticism, openness to experience, ability to compromise, self-regulation, etc. are its determinants (Gramzow et al, 2004).

It should be noted that the affective sphere in general and its individual issues in the age aspect have been analyzed and researched in various ways, but the psychological factors of emotional instability in adolescents have only been covered fragmentarily in scientific achievements (Benard, n.d., 1991; Gramzow et al.). Thus, a four-dimensional analysis of emotions in the planes of emotional frequency, intensity, instability, and clarity has been described by Bailen, Green, and Thompson (2019); the correlation between the pursuit of hypermasculinity and emotion regulation has been established by Roche et al (2021); the phenomenon of emotional socialization in the father-adolescent- 
friends triad was investigated by Miller-Slough and Dunsmore (2020); the impact of negative emotions on adolescents' prosocial and aggressive behaviors was addressed by Mesurado, Vidal, and Mestre (2018); low emotion regulation capacity as a determinant of adolescent eating disorders was described in Brown, Hochman, and Micali (2020).

For theoretical substantiation of the problem of the affective sphere of adolescents, we used freely available scientific research results published in journals and placed in repositories of educational institutions, on the websites of research teams and individual researchers. For convenience, we used the capabilities of search engines and scientific resources (Google Scholar, Elsevier, Researchgate), as well as specialized scientific information databases: MDPI (Molecular Diversity Preservation International), EBSCO, ScienceDirect.

Considering the above analysis of scientific sources, the description and systematization of psychological factors of emotional instability in adolescents is a relevant and promising area of psychological research. In the available works we notice that the emphasis is made on external factors: physiological changes and socio-psychological bases of emotional instability of teenagers (influence of parents, relatives, communication with peers, reformatting self-perception of own "I" and body image) that, certainly, is important for understanding of the raised problem. Considering that the internal determinants of adolescents' emotional instability have not been sufficiently investigated, their identification and analysis makes our study unique and relevant. According to this, the purpose of the research work is to empirically investigate and identify psychological factors of personal emotional instability during her experience of puberty.

Materials and methods. The empirical part of research of internal psychological factors of personal emotional instability of teenagers is based on the ascertaining experiment, carried out among pupils of 6-7 and 8-9 classes of establishments of the general secondary education of the Ternopol region (Berezhanska comprehensive school №1 and Berezhanska comprehensive school №2). Since the study provides for the study of peculiarities of a certain age stage, the sample was constructed on the basis of age features of the respondents. In total it consisted of 300 students who were offered a package of psychodiagnostic techniques to determine the levels of emotional stability of the personality and indicators of potential psychological factors of development of emotional stability of the personality, relevant to the positive emotional development of the teenager during his experience of the crisis period.

The materials of the research were the available scientific developments in the field of research of features of the emotional sphere of teenagers.

At the stage of data collection - a package of psychodiagnostic methods specific to the specified problem; at the stage of processing of the results obtained methods of parametric statistics and factor analysis. techniques:

In particular, when implementing the ascertaining experiment, we used the following

- G. Eysenck's "Emotional Stability/Instability Scale," proposed by E. P. Ilin (Ilin, 2001, p. 551-553);

- "Individual-typological questionnaire" by L. M. Sobchik (Sobchik, 2005, p. 64-72);

- "Self-esteem and Attitude Scale" by T. Dembo and S. Ya. Rubinstein, modified by A. M. Prikhozhan (Prikhozhan, 1988, p. 110-128);

- “Assessment of Emotional Intelligence" by N. Hall (Fetiskin et al., 2002, p. 41-42);

- A. Furman's "Personal Adaptability Questionnaire for Schoolchildren" (Furman, 2000, p. 49-61);

- A. V. Zvierkov and E. V. Eidman's methodology of research of volitional self-regulation. (Lemak, \& Petryshch, (Eds.), 2012, p. 63-67);

- "Forecast" (assessment of the level of neuro-psychological firmness according to V. Bodrov) (Lemak \& Petryshch, (Eds.), 2012, p. 12-16);

- Diagnostic technique of communicative and organizational aptitudes (COA-2) (Fetiskin et al., 2002, p. 184-186).

The purpose of the ascertaining experiment was to study the features of manifestation and factors of emotional stability of younger and older teenagers. Accordingly, the architectonics of the practical part of the research consisted of:

1. Study and compare features of the level of manifestation of indicators of emotional stability of younger (students in grades 6-7) and older (students in grades 8-9) adolescents. 
2. Study and comparison of features of manifestation of hypothetical psychological factors of development of emotional stability in the group of younger adolescents, students of 6th-7th grades of general educational institutions.

3. Study and comparison of features of manifestation of hypothetical psychological factors in the development of emotional stability in the group of older adolescents, students in grades 8-9 of general educational institutions.

4. Analysis of correlations between features of manifestation of emotional resilience and potential factors in the groups of younger (students of 6th-7th grades) and older (students of 8th-9th grades).

5. Allocation of groups of factors for the development of emotional resilience of adolescents.

The data obtained as a result of the ascertaining experiment were analyzed using Microsoft Excel and parametric statistical methods provided in the statistical software package SPSS 21. To establish the main groups of factors for the development of emotional resilience, factor analysis using the principal components method with subsequent Varimax rotation was used, limiting the factor weight of the factor's components to not less than 0.4 . The choice of factor analysis as a method of data processing is due to the fact that group data matrices allow the identification of a smaller number of factors compared to individual ones, since only those bases of categorization that are invariant with respect to the entire sample of subjects can become factors.

Results. As a result of our factor analysis, we identified groups of factors in each of the proposed elements that determine the factors of emotional instability in adolescents.

It was found that the emotional instability of adolescents is determined by 10 factors, described below (Table 1).

Thus, the first factor includes the following variables: overestimated self-esteem $(-0.625)$, adequate average self-esteem (0.434), overestimated pretentions (-0.628), and realistic high pretentions $(0.406)$, forming $29.2 \%$ of the total variance. The primary factor reflects the ambivalence of the individual in the assessment of his/her own self and personal life aspirations. The content of this factor was interpreted as an imbalance of self-esteem and personal abilities.

The second factor $(35,3 \%$ of the total variance) has the following variables: average level of emotional stability $(0,480)$, inflated level of self-esteem $(-0,466)$, high volitional self-regulation $(0,485)$, low volitional self-regulation $(-0,432,4)$, self-control It indicates the contradiction in selfesteem of personality and the desire to control their own emotions studied. In our opinion, this is due to the difficulties of the studied difficulties of the crisis age period. The child's inadequate self-esteem provokes psychological defense mechanisms, which manifest themselves in the desire to control themselves and their emotions in an emotionally stressful situation. To characterize this factor, we defined the concept of "personal insecurity" compensated by self-control.

The third factor (40,8\% of variance) is largely determined by two variables: an average level of stress resistance $(-0,731)$ and a low level of stress resistance $(-0,645)$. The third factor reflects the peculiarities of stress-resistant potentials of adolescents with a tendency to worsen. We define its content as "low stress resilience".

The fourth factor $(45,9 \%$ of the total variance) of emotional instability includes the following variables: spontaneity $(0,419)$, adequate high self-esteem $(-0,405)$, undervalued self-esteem $(0,483)$, realistic average level of pretensions $(0,446)$ and undervalued $(0,469)$. The indicated factor reflects the manifestation of liberated self-assertion, pronounced adolescent impulsiveness on the background of ambivalence of self-esteem and personal aspirations of the adolescent. As a characteristic of the fourth factor, we offer the statement "impulsiveness on the background of insecurity".

The fifth factor (50.8\% of the total variance) of adolescents' emotional instability contains the following variables: elevated self-esteem $(-0.414)$, adequate high self-esteem $(0.660)$, adequate average self-esteem $(-0.471)$. It reflects the contradiction in the self-esteem of the studied and designated by us as a dissonance of self-esteem.

The sixth factor $(55.6 \%$ of the total variance) is filled with the following variables: introversion (-0.467) and overestimation (-0.414). The tandem of these variables reflects adolescents' contradiction in striving for openness, activity, and action and simultaneous intrapersonal conflict between what the adolescent strives for and what he or she believes is possible. We define the sixth factor as "motivational polarity".

The seventh factor ( $60.3 \%$ of the total variance) has the following content: an average level of emotional toughness $(-0.500)$, a low level of emotional toughness $(0.422)$, an underestimated level of self-esteem (0.443) and is characterized by us as "emotional uncertainty". 
The eighth factor (65\% of the total variance) of emotional instability accumulates the following variables: the difference between the level of self-esteem and the level of pretensions (0.417), communication abilities (0.487), organizational abilities $(0.450)$. We characterize this factor as "tendency to public insecurity".

The ninth factor ( $69 \%$ of the total variance) of emotional instability includes one variable: realistic average level of pretensions (-0.482). It illustrates the unrealistic aspirations of an adolescent, often caused by adolescent maximalism and simultaneous insecurity, so we interpret the meaning of the ninth factor as "insecurity in one's own abilities".

The last, tenth factor of emotional instability (73\% of the total variance), included the following variables: aggressiveness (0.388) and an underestimated level of pretensions (-0.416). The tenth factor indicates adolescents' tendency to excessive and impulsive expression of negative emotions, hostility in combination with hyperbole of their own abilities, which often leads to frustration. We interpret its content as "aggressively confident behavior".

Table 1. Factor loads for the study group $(>, 400)$

\begin{tabular}{|c|c|c|}
\hline Factor & Scale name & Factor loads \\
\hline \multirow{4}{*}{$\begin{array}{c}\text { Factor } 1 \text { "Imbalance of self- } \\
\text { esteem and personal } \\
\text { capabilities" }\end{array}$} & Overrated level of self-esteem &,- 625 \\
\hline & Adequate average level of self-esteem & ,434 \\
\hline & Exaggerated self-esteem &,- 628 \\
\hline & Realistic high level of pretensions & ,406 \\
\hline \multirow{5}{*}{$\begin{array}{l}\text { Factor } 2 \text { "Personal Insecurity } \\
\text { Compensated by Self-Control" }\end{array}$} & Average level of emotional stability & 480 \\
\hline & Exaggerated level of self-esteem &,- 466 \\
\hline & High volitional self-regulation &, 485 \\
\hline & Low willful self-regulation &,- 432 \\
\hline & Self-control &, 430 \\
\hline \multirow{2}{*}{$\begin{array}{c}\text { Factor } 3 \text { "Low stress } \\
\text { tolerance" }\end{array}$} & Average level of stress resistance &,- 731 \\
\hline & Low level of stress tolerance &,- 645 \\
\hline \multirow{5}{*}{$\begin{array}{c}\text { Factor } 4 \text { "Impulsiveness on } \\
\text { the background of } \\
\text { uncertainty" }\end{array}$} & Spontaneity & ,419 \\
\hline & Adequate high level of self-esteem &,- 405 \\
\hline & Underestimated level of self-esteem & ,483 \\
\hline & Realistic average level of pretensions & ,446 \\
\hline & Underestimated level of pretensions & ,469 \\
\hline \multirow{3}{*}{$\begin{array}{c}\text { Factor } 5 \text { "Dissonance of self- } \\
\text { esteem" }\end{array}$} & Overrated level of self-esteem &,- 414 \\
\hline & Adequate high level of self-esteem &, 660 \\
\hline & Adequate medium level of self-esteem &,- 471 \\
\hline \multirow{2}{*}{$\begin{array}{c}\text { Factor } 6 \text { "Motivational } \\
\text { Polarity" }\end{array}$} & Introversion &,- 467 \\
\hline & Exaggerated level of pretensions &,- 414 \\
\hline \multirow{3}{*}{$\begin{array}{c}\text { Factor } 7 \text { "Emotional } \\
\text { uncertainty" }\end{array}$} & Average level of emotional resilience &,- 500 \\
\hline & Low level of emotional toughness &, 422 \\
\hline & Lowered level of self-esteem & ,443 \\
\hline \multirow[t]{3}{*}{$\begin{array}{l}\text { Factor } 8 \text { "Propensity for } \\
\text { public uncertainty" }\end{array}$} & $\begin{array}{l}\text { Difference between the level of self-esteem } \\
\text { and the level of pretensions }\end{array}$ & 417 \\
\hline & Communicative skills & ,487 \\
\hline & Organizational abilities &, 450 \\
\hline $\begin{array}{l}\text { Factor } 9 \text { "Lack of self- } \\
\text { confidence" }\end{array}$ & Realistic average level of pretensions &,- 482 \\
\hline \multirow{2}{*}{$\begin{array}{c}\text { Factor } 10 \text { "Aggressively } \\
\text { Confident" }\end{array}$} & Aggressive & ,388 \\
\hline & Underestimated level of pretensions &,- 416 \\
\hline
\end{tabular}

Source: Results of the ascertaining experiment

Thus, factor analysis has established 10 psychological factors that cause emotional instability in adolescents, including imbalance of self-esteem and personal abilities, compensated by self-control personal insecurity, low resistance to stress, impulsiveness against the background of uncertainty, dissonance in the assessment of their own self, motivational polarity, emotional uncertainty, public insecurity, lack of confidence in their own abilities, aggressive-confident behavior. 
Discussion. The dynamism and cardinality of what happens during puberty actualizes the problem of studying the affective sphere of personality at this age stage. Our study partially filled a gap in our understanding of the nature of emotional instability in adolescents, in particular, the nature of the origin of its internal determinants. The sample that included 300 respondents was representative, and the data obtained as a result of the fact-finding experiment were reliable. A limitation of the study was the failure to take into account the gender identity of those involved in the study.

Another limitation of obtaining reliable data in studying the emotional sphere of adolescents is the subjectively immanent nature of emotional life and conformism, typical for this age. Thus, the intensity of experience of this or that emotion in each individual may vary and depend on previous experiences. By the way, one of the properties of emotions is their dynamism and variability compared to, say, mood, temperament, or character. Therefore, passing the same psychodiagnostic technique, depending on the overall emotional background at the time of the study, may yield different results in the end. Because most techniques involve collecting information regarding personal experiences, respondents may consciously or unconsciously provide false data that they believe will meet the researcher's expectations or make them appear better, more successful, etc.

The review of the available literature, concerning the problem of the factors of emotional instability, though showed the global character of the study of the problem, turned out to be limited in the perspective of the ethno-national and socio-cultural one. It is obvious that, say, the Asian style of upbringing differs from the European, and this, in turn, affects the experience of the individual, forming certain patterns of behavior in general and emotional in particular. Yes, in the minds of boys there is a stereotype: "Men don't cry", in the minds of girls - "Cry, it'll do you good". Such conative paradigms put a person before the need to meet certain social expectations in their emotional reactions: to hide or, on the contrary, to brightly demonstrate their emotional state. And this, in turn, affects the validity of the research data, however, creates a platform for a more in-depth study of the topic of emotional stability of adolescents.

Preparing for the experimental part of the study, we came to the conclusion that the psychodiagnostic toolkit needs to be updated, taking into account the immanent nature of the emotional life of modern adolescents. However, despite this limitation, we were able to achieve our goals: to identify and describe psychological factors in the emotional instability of adolescents.

The empirical part of the conducted research, first, actualizes the problem of studying the affective sphere of adolescents, contributes to the systematization of exactly internal factors of emotional instability of adolescents' personality, and second, will be useful for familiarization by practical psychologists and teachers working with schoolchildren of adolescent age.

Conclusions. Available research (Mesurado et al, 2018; Bailen et al, 2019; Brown et al, 2020; Miller-Slough, \& Dunsmore, 2020; Roche et al, 2021) updates and confirms the promise of affective research. These researchers attempt to conduct studies differentiating respondents by gender, although in our opinion, there is a clear lack of disclosure of gender differences in the expression and dysregulation of emotions. We can assume that the determinants in this case are social and cultural traditions of the environment. At the same time, the presence of debatable issues and contradictory moments opens the field for new in-depth research in the direction of psychological and direct emotional stability of personalities of all ages.

A review of sources demonstrates fragmentary study and isolated attempts to systematize the factors of personal emotional instability (Benard, n.d., 1991; Gramzow et al, 2004) with an emphasis on external determinants.

We believe that emotional stability is a polyvector definition that should include not only the very important, external: family, social, cross-cultural, gender, psychophysiological features of adolescents' life functioning considered by the above authors, but also a multifaceted internal component in itself such aspects of personality formation of the modern teenager as self-esteem, selfcontrol, motivation, self-confidence, independence, adaptability, emotional intelligence, etc. This thesis finds direct confirmation in the results of the research conducted and described in the article.

For a long time, scientists considered the pubertal period primarily through the prism of the age crisis, without delving into the individual structural components of the mental life of adolescents. To fill the gap in understanding exactly the psychological factors of the emotional instability of teenagers, we conducted a fact-finding experiment where the prerogative was to study the personality of an adolescent, his inner world, formed not only under the influence of family, society, various offline and online communications, but also endowed with a variety of individual, intrapsychological, personal-subjective features and qualities. 
The specific for this experiment package of methods directed on research of emotional stability/instability of the personality, self-esteem, emotional intelligence, nervous-psychological firmness, etc., allowed us to study not only the features of the level of emotional stability of teenagers, but also categories of hypothetical factors. The data processed by factor analysis allowed us to identify 10 psychological factors that determine the emotional instability of adolescents: imbalance of selfesteem and personal abilities, compensated by self-control personal insecurity, low resistance to stress, impulsiveness against insecurity, dissonance in assessment polarity, emotional uncertainty, public insecurity, insecurity in own strength, aggressively confident behavior.

The significance of the obtained results lies in the fact that targeted influence on the identified factors of adolescents' emotional instability will allow to develop emotional stability of this age group through engaging a person-centered approach in psychological work with adolescents. Empirically investigated factors of adolescents' emotional instability open the prospect of further studies in this direction, which consists in the development and practical implementation of the socio-psychological training, aimed at developing the emotional stability of persons of this age group.

Declaration of interest statement. The authors declare no conflict of interest.

\section{REFERENCES}

1. Bailen, N. H., Green, L. M., \& Thompson, R. J. (2019). Understanding emotion in adolescents: A review of emotional frequency, intensity, instability, and clarity. Emotion Review: Journal of the International Society for Research on Emotion, 11(1), 63-73. https://doi.org/10.1177/1754073918768878

2. Benard, B. (n.d.). Fostering resiliency in kids: Protective factors in the family, school, and community. Nationalresilienceresource.Com. $\quad$ Retrieved November 30, 2021, from http://www.nationalresilienceresource.com/BB_Fostering_Resilience_F_9_2012.pdf

3. Brown, M., Hochman, A., \& Micali, N. (2020). Emotional instability as a trait risk factor for eating disorder behaviors in adolescents: Sex differences in a large-scale prospective study. Psychological Medicine, 50(11), 1783-1794. https://doi.org/10.1017/S0033291719001818

4. Cheung, R. Y. M., Chan, L. Y., \& Chung, K. K. H. (2020). Emotion dysregulation between mothers, fathers, and adolescents: Implications for adolescents' internalizing problems. Journal of Adolescence, 83, 62-71. https://doi.org/10.1016/j.adolescence.2020.07.001

5. Fetiskin, N. P., Kozlov, V. V., \& Manuylov, G. M. (2002). Sotsialno-psikhologicheskaya diagnostika razvitiya lichnosti i malykh grupp [Socio-psychological diagnostics of the development of personality and small groups]. Moskva: Izdatelstvo Instituta Psikhoterapii. (in Russ.).

6. Furman, A. V. (2000). Psykhodiahnostyka osobystisnoi adaptovanosti: Naukove vydannia. [Psychodiagnostics of personal adaptability: Scientific publication]. Ternopil: Ekonomichna dumka. (in Ukr.).

7. Gramzow, R. H., Sedikides, C., Panter, A. T., Sathy, V., Harris, J., \& Insko, C. A. (2004). Patterns of selfregulation and the big five. European Journal of Personality, 18(5), 367-385. https://doi.org/10.1002/per.513

8. Ilin, E. P. (2001). Emotsii i chuvstva [Emotions and feelings]. Sankt-Peterburg: Piter. (in Russ.).

9. Lemak, M. V., Petryshch, V. Yu. (Eds.). (2012). Psykholohu dlia roboty. Diahnostychni metodyky [Psychologist for work. Diagnostic techniques]. Uzhhorod: Vydavnytstvo Oleksandry Harkushi. (in Ukr.).

10. Mendo-Lázaro, S., León-Del-Barco, B., Polo-Del-Río, M.-I., Yuste-Tosina, R., \& López-Ramos, V.-M. (2019). The role of parental Acceptance Rejection in emotional instability during adolescence. International Journal of Environmental Research and Public Health, 16(7), 1194. https://doi.org/10.3390/ijerph16071194

11. Mesurado, B., Vidal, E. M., \& Mestre, A. L. (2018). Negative emotions and behaviour: The role of regulatory emotional self-efficacy. Journal of Adolescence, 64, 62-71. doi: 10.1016/j.adolescence.2018.01.007

12. Miller-Slough, R. L., \& Dunsmore, J. C. (2020). Emotion socialization by parents and friends: Links with adolescent emotional adjustment. Journal of Applied Developmental Psychology, 71(101197), 101197. https://doi.org/10.1016/j.appdev.2020.101197

13. Prikhozhan, A. M. (1988). Primeneniye metodov pryamogo otsenivaniya $v$ rabote shkolnogo psikhologa [Application of direct assessment methods in the work of a school psychologist]. Moskva: Izdatelstvo APN SSSR. (in Russ.).

14. Roche, C., Trompeter, N., Bussey, K., Mond, J., Cunningham, M. L., Murray, S. B., Lonergan, A., \& Mitchison, D. (2021). Gender compatibility and drive for muscularity among adolescent boys: Examining the indirect effect of emotion regulation difficulties. Body Image, 39, 213-220. doi: 10.1016/j.bodyim.2021.08.009

15. Sobchik, L. N. (2005). Psikhologiya individualnosti. Teoriya i praktika psikhodiagnostiki. [Psychology of personality. Theory and practice of psychodiagnostics]. Sankt-Peterburg: Rech. (in Russ.). 